\title{
Population-based surveillance of invasive group A streptococcal disease in British Columbia: 1996 to 1998
}

\author{
Gordean L Bjornson MBA ${ }^{1}$, David W Scheifele MD ${ }^{1}$, Alison Bell MDCM${ }^{2}$, Arlene King MDCM²
}

\begin{abstract}
GL Bjornson, DW Scheifele, A Bell, A King. Population-based surveillance of invasive group A streptococcal disease in British Columbia: 1996 to 1998. Can J Infect Dis 2001;12(4):232-236.

OBJECTIVE: To identify and describe all cases of invasive group A streptococcal (GAS) infection occurring in British Columbia during a two-year period.

DESIGN: Active, laboratory-based surveillance with supplemental case description.

SETTING: Forty community and regional hospitals and the provincial laboratory participated, encompassing all health regions. POPULATION STUDIED: Entire provincial population from April 1, 1996 to March 31, 1998.

MAIN RESULTS: Over the 24-month surveillance period, 182 eligible cases were identified, yielding a mean annual incidence rate of 2.3/100,000. Patients ranged in age from two to 91 years, with a mean of 39.1 years. Soft tissue infections accounted for 89 of 130 cases $(68.5 \%)$ with a defined clinical syndrome, 20 of which were necrotizing fasciitis. Injection drug use was described in 55 patients, who, as a group, were younger, more likely to have soft tissue infections and less likely to die of infection than nondrug users. Other risk factors for infection included HIV infection (19 patients); skin damage (26 patients, damage independent of injection drug use); chronic illness (27 patients); and immunosuppresion (three patients). Death from GAS infection occurred in 15 of $131(11.5 \%)$ cases with known outcome, yielding an annual case fatality rate of 1.9/million population. Among necrotizing faciitis cases, the mortality rate was $30 \%$.

CONCLUSIONS: Invasive GAS infections are rare in British Columbia and tend to involve persons with chronic illness or prior skin trauma, especially injection drug abuse, which accounted for nearly half of the cases.
\end{abstract}

Key Words: Invasive group A streptococcal infections; Necrotizing fasciitis

pour le résumé, voir page suivante

\footnotetext{
${ }^{1}$ Vaccine Evaluation Centre, University of British Columbia, Vancouver, British Columbia; ${ }^{2}$ Epidemiology Services, British Columbia Centre for Disease Control Society, Vancouver, British Columbia

Correspondence: Mr Gordean L Bjornson, Vaccine Evaluation Centre, 4500 Oak Street, Room L427, Vancouver, British Columbia V6H $3 N 1$.

Telephone 604-875-2422, fax 604-875-2635, e-mail gbjornson@cw.bc.ca

Received for publication December 16, 1999. Accepted July 12, 2000
} 


\title{
Surveillance, dans la population, des infections invasives à streptocoques A en Colombie- Britannique entre 1996 et 1998
}

\begin{abstract}
OBJECTIF : Relever et décrire tous les cas d'infection invasive à streptocoques A (strep. A), enregistrés en ColombieBritannique sur une pério-de de deux ans.

PLAN D'ÉTUDE : Surveillance active, fondée sur des examens de laboratoire et accompagnée de descriptions de cas.

LIEU : Quarante hôpitaux régionaux et communautaires, de même que le laboratoire provincial, englobant toutes les régions sanitaires, ont participé à l'étude.

POPULATION À L'ÉTUDE : Toute la population de la province, entre le 1er avril 1996 et le 31 mars 1998.

PRINCIPAUX RÉSULTATS : Sur la période de surveillance de 24 mois, 182 cas admissibles ont été recensés, ce qui porte à 2,3/100 000 habitants le taux moyen annuel d'incidence. Lâge des patients variait de 2 ans à 91 ans, et la moyenne se situait à 39,1 ans. Il y a eu atteinte des tissus mous dans 89 cas sur 130 (68,5\%), accompagnée d'un syndrome clinique défini; une fasciite nécrosante a été observée dans 20 cas. On a fait état d'utilisation de drogues injectables chez 55 patients, qui, en tant que groupe, étaient plus jeunes, plus susceptibles de présenter une infection des tissus mous et moins susceptibles de succomber à la maladie que les non-utilisateurs de drogues. Parmi les autres facteurs de risque, mentionnons l'infection à VIH (19 patients), les lésions cutanées (26 patients; autres lésions que celles causées par les injections de drogues), les maladies chroniques (27 patients) et l'immunosuppression (3 patients). On a enregistré 15 décès sur 131 cas (11,5\%) d'infection invasive à strep. A; le taux annuel de létalité s'élève donc à 1,9/1 000000 habitants. Quant au taux de mortalité, il a atteint $30 \%$ dans les cas de fasciite nécrosante.

CONCLUSION : Les infections invasives à strep. A sont rares en Colombie-Britannique et ont tendance à se produire chez les personnes souffrant de maladies chroniques ou portant des lésions cutanées, attribuables notamment à l'utilisation de drogues injectables; ces facteurs expliquent à peu près la moitié des cas.
\end{abstract}

$S_{\text {tres }}^{\mathrm{tr}}$ treptococcal toxic shock syndrome (STSS), necrotizing asciitis (NF) and other invasive disease due to group A streptococci (GAS) have been subjects of considerable attention in recent medical literature and lay press (1-7). Concerns over apparent increases in the incidence rate and severity of GAS infections have prompted population-based surveys (1-3) and changes in regulations to make invasive infections reportable in some jurisdictions. The purpose of this study was to obtain accurate, prospective data on invasive GAS infections in British Columbia in anticipation of new reporting requirements.

\section{DATA AND METHODS}

From April 1, 1996 to March 31, 1998, the authors attempted to identify and describe all hospital admissions for invasive GAS infection in persons living in British Columbia. Invasive disease was defined by the isolation of Streptococcus pyogenes from a normally sterile body site, not including cervical lymph nodes. Streptococcal NF was further defined by histopathology or the presence of frank necrosis (gangrene) at surgery or on physical examination. STSS was defined by the isolation of GAS from a normally sterile body site, and the presence of hypotension and at least two of the following: generalized erythematous rash, coagulopathy, liver injury, adult-type respiratory distress syndrome, renal impairment or soft tissue necrotic disease, including necrotizing fasciitis, myositis or gangrene (1).

Case finding was based on active surveillance of hospital microbiology laboratories. A laboratory network was established involving 40 hospitals that provide virtually all of the provincial microbiology services, including all larger community hospitals, regional hospitals and the provincial laboratory. Regional hospitals provide laboratory services to the smaller community hospitals, which were not included in the network. Laboratories were contacted by fax every second month requesting information on any new cases since the previous contact or confirmation that none had been encountered. Laboratory responses were tracked to ensure compliance with the bimonthly requests. When a new case was identified, the laboratories provided personal identifiers, age, sex, and date and source of positive culture. Clinical details were obtained by survey staff from attending physicians and hospitals. Isolates were identified by hospital laboratories using routine criteria.

Following completion of the survey, a reporting audit was performed at 48 hospitals. These included the 40 participating hospitals plus eight other small hospitals that were excluded because they did not perform microbiological tests at the start of surveillance in 1996. Each laboratory was sent a list of cases that it had reported during the survey with a request to review this against source lists and confirm the completeness of reporting or add any missed cases.

A standardized report form was used to abstract case information. Case reports were entered into a database (Access Version 7.0, Microsoft Corporation, USA) and analyzed using SAS Version 6.0 (SAS Institute, USA). Population data for calculating incidence rates were obtained from British Columbia Regional Populations Projections (PEOPLE).

Ethics approval was obtained from the University of British Columbia Clinical Research Ethics Board.

\section{RESULTS}

During the 24-month surveillance period, 182 invasive GAS cases, consistent with the case definition, were identified. Laboratory-derived information (patient age and sex, date and source of positive cultures) was available for all cases, while clinical details were available for 130 cases (71.0\%). The mean age of affected individuals was 39.1 years, ranging from two to 91 years. $53.3 \%$ of patients were male. The 52 patients for whom clinical details could not be obtained were similar to the other 130 patients in terms of age (mean 39.4 years), sex ratio (males $40.5 \%$ ), frequency of 
TABLE 1

Age distribution of invasive group A streptococcus cases, British Columbia, April 1, 1996 to March 31, 1998

\begin{tabular}{|c|c|c|c|c|}
\hline $\begin{array}{l}\text { Age (years) } \\
\text { at admission }\end{array}$ & $\begin{array}{c}\text { Number of cases, April 1, } 1996 \\
\text { to March 31, } 1997(\%)\end{array}$ & $\begin{array}{c}\text { Number of cases, April 1, } 1997 \\
\text { to March } 31,1998(\%)\end{array}$ & $\begin{array}{l}\text { Total number of cases } \\
\text { by age group }(\%)\end{array}$ & $\begin{array}{l}\text { Mean annual incidence } \\
\text { rate per } 100,000\end{array}$ \\
\hline$<10$ & $5(5.3 \%)$ & $9(10.3 \%)$ & $14(7.7 \%)$ & 1.4 \\
\hline 10 to 19 & $4(4.2 \%)$ & $9(10.3 \%)$ & $13(7.1 \%)$ & 1.3 \\
\hline 20 to 29 & $17(17.9 \%)$ & $12(13.8 \%)$ & 29 (15.9\%) & 2.6 \\
\hline 30 to 39 & $25(26.3 \%)$ & $25(28.8 \%)$ & $50(27.6 \%)$ & 3.7 \\
\hline 40 to 49 & $21(22.1 \%)$ & $10(11.5 \%)$ & $31(17.0 \%)$ & 2.5 \\
\hline 50 to 59 & 8 (8.4\%) & $6(6.9 \%)$ & $14(7.7 \%)$ & 1.7 \\
\hline$\geq 60$ & $14(14.7 \%)$ & $15(17.3 \%)$ & $29(15.9 \%)$ & 2.2 \\
\hline Unknown & $1(1.1)$ & $1(1.1 \%)$ & $2(1.1 \%)$ & \\
\hline \multicolumn{5}{|c|}{ Total annual number } \\
\hline
\end{tabular}

\section{TABLE 2}

Primary clinical syndrome and outcome of invasive group A streptococcus in cases with complete clinical information available

\begin{tabular}{lccc}
\hline Infection & $\begin{array}{c}\text { Total number } \\
\text { of cases }\end{array}$ & $\begin{array}{c}\text { Number of } \\
\text { STSS cases }\end{array}$ & $\begin{array}{c}\text { Fatality } \\
\text { rate (\%) }\end{array}$ \\
\hline Bacteremia & 13 & 1 & 15.4 \\
$\quad$ Without focus & 2 & 0 & 0 \\
With tonsillitis & 10 & 2 & 40.0 \\
With pneumonia & 1 & 1 & 100 \\
$\quad$ With other possible sites & & & \\
Cellulitis & 51 & 0 & 2.0 \\
$\quad$ Only & 9 & 0 & 0 \\
With additional sites & 1 & 0 & 0 \\
$\quad$ Surgical wound infection & 20 & 7 & 30.0 \\
Necrotizing fasciitis & & & \\
Other & 4 & 1 & 0 \\
$\quad$ Peritonitis & 4 & 0 & 0 \\
Osteomyelitis & 9 & 1 & 11.1 \\
Septic arthritis & 1 & 0 & 0 \\
Puerperal sepsis & 5 & 0 & 0 \\
$\quad$ Other & 130 & 12 & 9.4 \\
Total (all infections) & & & \\
\hline STS Steptococcl toxis & & & \\
\hline
\end{tabular}

STSS Streptococcal toxic shock syndrome

positive blood cultures ( $75.0 \%$ versus $82.6 \%$, respectively) and geographic distribution. Hospitals in greater Vancouver reported $80 \%$ of the cases, although cases were reported from 19 of 20 health regions in the province.

The observed mean annual incidence rate of invasive GAS infection was 2.3 cases/100,000, based on a total population of 3.94 million during this time. The peak incidence rate was 3.7/100,000/year among persons aged 30 to 39 years old (Table 1), who accounted for over one-quarter of the case total.

Among 130 patients described in detail, a defined site of infection was present in $90 \%$, while $10 \%$ had bacteremia with no localized infection site. Soft tissue was the most common primary site of infection, involving 94 patients $(72.3 \%)$ (Table 2$)$. Hypotension was reported in 18 cases (13.8\%) with 10 deaths (55.6\%). Twelve of those patients met the definition of toxic shock syndrome, and nine patients died (75.0\%). Four additional patients might have had
TABLE 3

Invasive group A streptococcus mortality by age group in cases with available outcome information

\begin{tabular}{|c|c|c|c|c|}
\hline $\begin{array}{l}\text { Fa } \\
\text { Age in } \\
\text { years }\end{array}$ & $\begin{array}{l}\text { atalities associated } \\
\text { with group A } \\
\text { streptococcus } \\
\text { infection }\end{array}$ & $\begin{array}{c}\text { dumber of } \\
\text { identified group A } \\
\text { streptococcus } \\
\text { cases }\end{array}$ & $\begin{array}{l}\text { Case } \\
\text { fatality } \\
\text { rate }(\%)\end{array}$ & $\begin{array}{c}\text { Mean annual } \\
\text { mortality rate } \\
\text { per million } \\
\text { population }\end{array}$ \\
\hline$<10$ & 0 & 12 & 0 & 0 \\
\hline 10 to 19 & 1 & 9 & 11.1 & 1.0 \\
\hline 20 to 29 & 1 & 20 & 5.0 & 0.9 \\
\hline 30 to 39 & 1 & 37 & 2.7 & 0.7 \\
\hline 40 to 49 & 3 & 26 & 11.5 & 2.4 \\
\hline 50 to 59 & 4 & 11 & 36.4 & 4.8 \\
\hline$\geq 60$ & 5 & 16 & 31.3 & 3.8 \\
\hline All ages & 15 & $131 *$ & 11.5 & 1.9 \\
\hline
\end{tabular}

*One case lacking other clinical details had outcome information

hypotension and/or STSS but died before or shortly after admission to hospital, limiting available documentation. The overall mortality rate among cases with a defined outcome was $9.4 \%$ (Table 2) or 1.9/million population/year (Table 3). The mortality rate was highest among persons 50 to 59 years old at 4.8/million/year.

NF was confirmed in 20 of 130 cases (15.4\%); clinical details were available for an additional two patients possibly having NF. Although case information was incomplete, one patient had cellulitis and possible fasciitis requiring debridement, and another had extensive cellulitis, hypotension and possible fasciitis but died before surgical confirmation. Among the remaining 52 cases, available information was sufficient to exclude the diagnosis of NF in each instance, yielding an overall rate of $12.1 \%$. The NF incidence rate was 2.8/million population/year. The mean age of NF patients was 35.9 years. There was weak evidence for a relationship between age and the occurrence of NF $(\mathrm{P}=0.076)$. The highest proportion of NF cases was seen among infected persons aged 50 to 59 years, $35.7 \%$ of whom had NF (Table 4 ). The largest number of cases $(n=6)$ was seen among persons 30 to 39 years old, but this represented only $12 \%$ of cases in this age group. No clustering of cases or seasonal pattern was evident. The mortality rate was $30 \%$ (Table 2 ). Injection drug use was noted as a risk factor in $15 \%$ of NF cases. Two of the 
TABLE 4

\begin{tabular}{lcc}
$\begin{array}{l}\text { Group A streptococcus (GAS) necrotizing fasciitis (NF) } \\
\text { by age group }\end{array}$ \\
\hline Age (years) at admission & NF cases & Total GAS cases (\% with NF) \\
\hline$<10$ & 3 & $14(21.4)$ \\
10 to 19 & 1 & $13(7.7)$ \\
20 to 29 & 2 & $29(6.9)$ \\
30 to 39 & 6 & $50(12.0)$ \\
40 to 49 & 4 & $31(12.9)$ \\
50 to 59 & 5 & $14(35.7)$ \\
$\geq 60$ & 1 & $29(3.4)$ \\
Unknown & 0 & $2(0)$ \\
All ages & $22^{*}$ & $182(12.1)$ \\
\hline
\end{tabular}

*Includes two possible cases, described in the text

three cases in children younger than 10 years of age were associated with chickenpox. All of the cases except one occurring in patients 50 years of age and older involved persons with chronic underlying conditions.

Risk factors for invasive GAS infection could be assessed in 123 cases. The most common risk factor was injection or intravenous drug use, which was noted in 55 cases (44.7\%) (Table 5). Insufficient information to determine drug use was available in seven other cases. Other risk factors or precipitating events leading to infection included HIV infection (15.4\%), although all HIV patients were also injection drug users. Trauma or prior surgery at the site of infection was evident in $22.1 \%$ of patients who were not injection drug users. Other risk factors included chronic illness (20.3\%) and alcoholism (4.9\%). No precipitating event or risk factor was noted in $21.1 \%$ of cases.

The mean age of injection drug users was 32.6 years (range 19 to 45 years). Over half $(52.7 \%)$ of the identified drug users were in the 30 to 39 years age group (Table 6). The proportion of patients using injection drugs was highest in this age group at $74.4 \%$, followed closely by the 20 to 29 years age group at $68.2 \%$, for patients with a defined drug use history.

The number of injection drug users in British Columbia's lower mainland was estimated by Schechter and O'Shaughnessy (8) to be 8700 (1217/100,000 population). Within this region, the authors identified 90 cases during the survey, of whom 39 cases (43.3\%) had injection drug use identified as a risk factor. The estimated incidence rate of invasive GAS infection in injection drug users in this region was 224/100,000/year compared with 3.6/100,000/year for the rest of the regional population $(\mathrm{P}<0.001)$.

\section{DISCUSSION}

This report presents the first detailed account of invasive GAS disease in British Columbia. We believe that our catchment of culture-confirmed cases was complete because our network included all hospital-based microbiology laboratories, and all laboratories cooperated with information requests, including an end-of-survey audit. Because both local and regional referral hospitals were included in the surveillance,
TABLE 5

Risk factors and/or precipitating events as related to injection drug use

\begin{tabular}{lccr}
\hline $\begin{array}{l}\text { Risk factor and/or } \\
\text { precipitating event }\end{array}$ & $\begin{array}{c}\text { Injection } \\
\text { drug user }\end{array}$ & $\begin{array}{c}\text { Injection drug } \\
\text { nonuser }\end{array}$ & Total \\
\hline Skin damage & 0 & 2 & 2 \\
Varicella & $5^{*}$ & 10 & 15 \\
Trauma only & 0 & 5 & 5 \\
Prior surgery only & 0 & 1 & 1 \\
Other only & 3 & 0 & 3 \\
Plus HIV & 0 & 5 & 5 \\
Plus alcoholism & 0 & 3 & 3 \\
Plus debilitating disease & & & \\
Debilitating disease & 2 & 6 & 8 \\
Cardiorespiratory & 0 & 3 & 3 \\
Diabetes & 0 & 1 & 1 \\
Alcoholism & 5 & 0 & 5 \\
Liver or renal insufficiency & 2 & 1 & 3 \\
Other & 5 & 0 & 5 \\
Plus HIV & 0 & 2 & 2 \\
Plus immunosuppression & & & \\
Immunosuppression & 11 & 0 & 11 \\
HIV & 0 & 3 & 3 \\
Other cause & 22 & 26 & 48 \\
No other risk factors noted & 55 & 68 & 123 \\
Total (all factors and/or events) & &
\end{tabular}

*Trauma in addition to that involved in using injection drugs

TABLE 6

Age distribution of invasive group A streptococcus cases in relation to defined injection drug use, British Columbia, April 1, 1996 to March 31, 1998

\begin{tabular}{lccc}
\hline Age group & $\begin{array}{c}\text { Number of } \\
\text { injection } \\
\text { drug users }\end{array}$ & $\begin{array}{c}\text { Number of } \\
\text { injection drug } \\
\text { nonusers }\end{array}$ & $\begin{array}{c}\text { Total (\% of cases } \\
\text { with injection } \\
\text { drug use) }\end{array}$ \\
\hline 10 to 19 years & 3 & 4 & $7(42.9 \%)$ \\
20 to 29 years & 15 & 7 & $22(68.2 \%)$ \\
30 to 39 years & 29 & 10 & $39(74.4 \%)$ \\
40 to 49 years & 8 & 18 & $26(30.8 \%)$ \\
All ages & 55 & 39 & $94(58.5 \%)$ \\
\hline
\end{tabular}

there was some duplication of case reporting, but these were easily reconciled. Case finding was not compared with hospital separation data. The main challenge was to obtain clinical details from attending physicians or hospitals to classify cases by syndrome and assess predisposing factors, because reporting of invasive GAS infections to public health authorities was not mandatory at the time. Details were ultimately obtained for $71.4 \%$ of cases, although limited information was available for all cases. Cases lacking clinical details did not differ from the others in mean age, source of positive cultures or geographic distribution. In this and other studies of invasive GAS, no attempt was made to include cellulitis cases for which the causative organism was inadequately investigated or not detected, but some of which could have been caused by GAS.

The mean annual incidence rate of invasive GAS infection in this survey $(2.3$ cases/100,000) was comparable with the rate of 1.5 cases/100,000 reported for Ontario (1) 
in 1992 to 1993 but lower than the rate of 5.2 cases/100,000 reported for Atlanta (2) in 1994 to 1995. All three reports were based on active, laboratory-based surveillance of defined populations.

The mean age of patients was similar in British Columbia and Ontario at 39.1 and 41 years, respectively. In Ontario and Atlanta, the incidence rate of GAS cases was highest among children younger than 10 years and in adults older than 59 years; however, in British Columbia, persons aged 30 to 39 years old had the highest rate. This difference likely reflects the high proportion of injection drug users among cases in British Columbia, who accounted for over one-half of the cases with an available drug use history (Table 6) and whose mean age was 32.6 years. In addition to the repeated skin trauma associated with injection drug use, such individuals were often suffering from HIV infection and/or other debilitating conditions. Schechter and O'Shaughnessy (8) described the difficult task of estimating injection drug use in British Columbia's lower mainland. Using their best estimate of the number of injection drug users, we calculated that the incidence rate of invasive GAS infection in injection drug users in this region was 62-fold higher than among the rest of the regional population. Data are lacking for other health regions of the province. Other studies also indicate that soft tissue infections are a common problem among injection drug users and often result from GAS (9-11). Soft tissue infection was notably more common in this series than in Ontario ( $72.3 \%$ versus $48 \%$ of cases, respectively), but among our cases not associated with injection drug use, the proportion of cases involving soft tissue infection was lower, at 37.0\%.

The proportion of cases involving (NF) was somewhat higher in British Columbia than in Ontario, at $10.9 \%$ and $6 \%$, respectively $\left(\mathrm{P}=0.055, \chi^{2}\right.$ test). The mean age of NF cases in British Columbia was 35.9 years, compared with 68 years in Ontario. Injection drug use was a possible factor in only $15 \%$ of NF cases in British Columbia, a smaller proportion than expected, given that almost half of the total cases detected by the study involved injection drug use. Among children, varicella is a frequent risk factor for NF (12). Routine varicella vaccination of children would prevent one paediatric case of $\mathrm{NF}$ annually in the province, based on the survey results. Almost all patients older than age 50 years with GAS infection also had chronic medical conditions, similar to the situation in Ontario.

STSS was present in $9.2 \%$ of cases in British Columbia and $13 \%$ of cases in Ontario. In both series, the mortality rate was much higher in persons with than without toxic shock. In British Columbia, the case fatality rate was $9.4 \%$ overall and $75.0 \%$ in persons with STSS, while the corresponding figures in Ontario were $15 \%$ and $81 \%$.

The surveys in British Columbia and Ontario differed in the proportion of cases having HIV infection - 14.6\% and 4\%, respectively - but this could be due, in part, to the surveys being conducted four years apart, during a time when HIV cas- es were on the rise. HIV infection was not an independent risk factor in the current series, because all patients were also injection drug users. Cardiorespiratory disease was reported more often as a risk factor among cases in Ontario (25\% versus $13.0 \%$ in British Columbia) in keeping with the peak incidence rate in persons 60 years of age or older. Diabetes and alcoholism were seen among cases with similar frequency in both provinces.

In summary, the results of two years of active populationbased surveillance suggest that invasive GAS infection is not common in British Columbia, occurring at an annual rate of $2.3 / 100,000$, a level comparable with that determined previously in Ontario. Injection drug users accounted for nearly half of the cases in British Columbia with a defined drug use history.

ACKNOWLEDGEMENTS: The authors thank Giselle Lightle and the Vaccine Evaluation Centre staff for their contribution to this study. Collection of case information would not have been possible without the help of numerous physicians, health records personnel, infection control nurses and microbiology technologists, to whom the authors are grateful. This project was funded by a grant from the British Columbia Centre for Disease Control Society.

\section{REFERENCES}

1. Davies HD, McGeer A, Schwartz B, et al. Invasive group A streptococcal infection in Ontario, Canada. N Engl J Med 1996;335:547-54.

2. Zurawski CA, Bardsley MS, Beall B, et al. Invasive group A streptococcal disease in metropolitan Atlanta: a populationbased assessment. Clin Infect Dis 1998;27:150-7.

3. Hoge CW, Schwartz B, Talkington DF, Breiman FR, MacNeill EM, Englender SJ. The changing epidemiology of invasive group A streptococcal infections and the emergence of streptococcal toxic shock-like syndrome: a retrospective population-based study. JAMA 1993;269:384-9.

4. Kiska DL, Thiede B, Caracciolo J, et al. Invasive group A streptococcal infections in North Carolina: epidemiology, clinical features, and genetic serotype analysis of causative organisms. J Infect Dis 1997:176:992-1000.

5. Kaplan EL. Recent epidemiology of group A streptococcal infections in North America and abroad: an overview. Pediatrics 1996;97:945-8.

6. Demers B, Simor AE, Vellend $\mathrm{H}$, et al. Severe invasive group A streptococcal infections in Ontario, Canada: 1987-1991. Clin Infect Dis 1993;16:792-800.

7. Zerr DM, Alexander ER, Duchin JS, Koutsky LA, Rubens E. A case-control study of necrotizing fasciitis during primary varicella. Pediatrics 1999;103:783-90.

8. Schechter MT, O'Shaughnessy MV. Distribution of injection drug users in the Lower Mainland. BC Med J 2000;42:80-1.

9. Bohlen LM, Muhlemann K, Dubuis O, Aebi C, Tauber MG. Outbreak among drug users caused by a clonal strain of group A streptococcus. Emerg Infect Dis 2000;6:175-9.

10. Summanen PH, Talan DA, Strong C, et al. Bacteriology of skin and soft-tissue infections: comparison of infections in intravenous drug users and individuals with no history of intravenous drug use. Clin Infect Dis 1995;20(Suppl 2):S279-82.

11. Bergstein JM, Baker EJ, Aprahamian C, Schein M, Wittmann DH. Soft tissue abscesses associated with parenteral drug abuse: presentation, microbiology, and treatment. Am Surg 1995;61:1105-8.

12. Laupland KB, Davies HD, Low DE, et al. Invasive group A streptococcal disease in children and association with varicella-zoster virus infection. Pediatrics 2000;105:e60. 


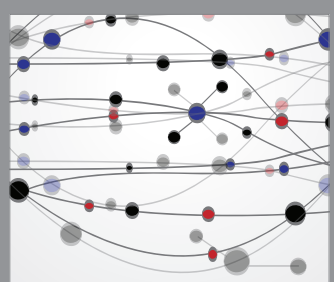

The Scientific World Journal
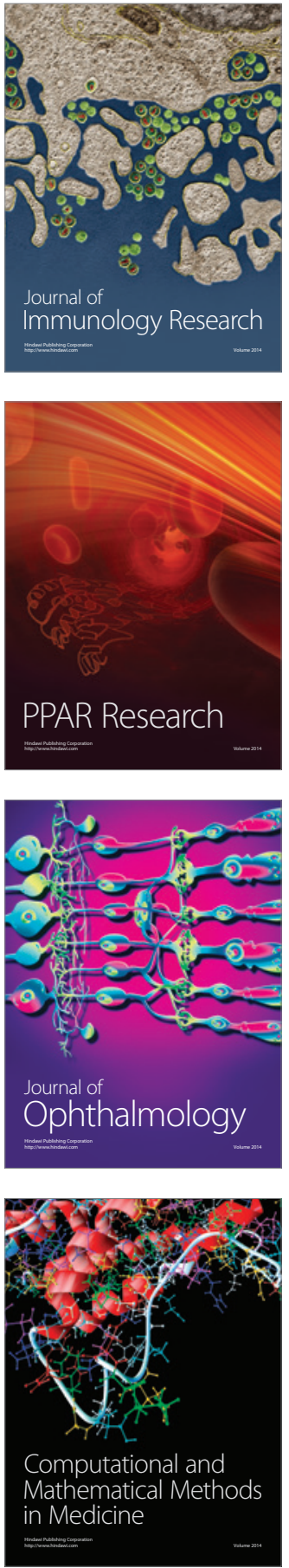

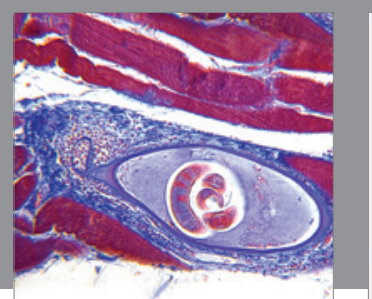

Gastroenterology Research and Practice

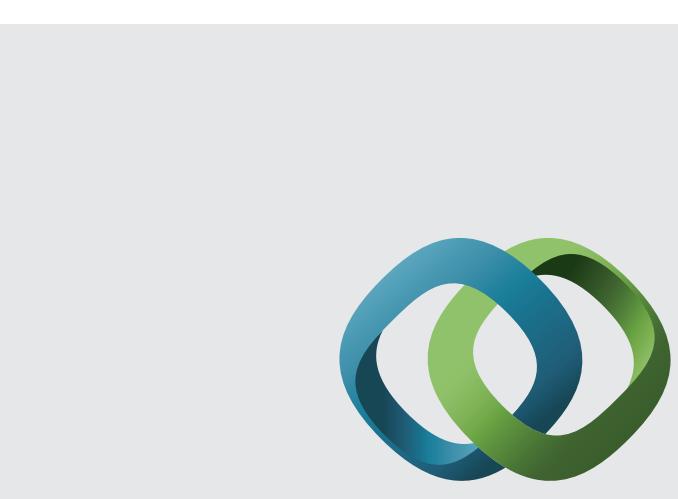

\section{Hindawi}

Submit your manuscripts at

http://www.hindawi.com
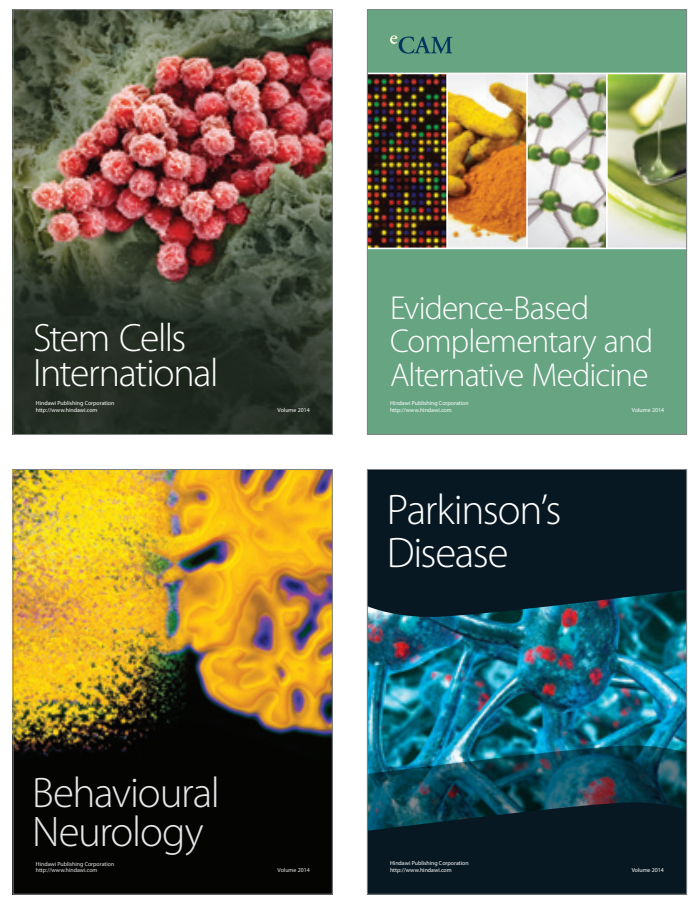
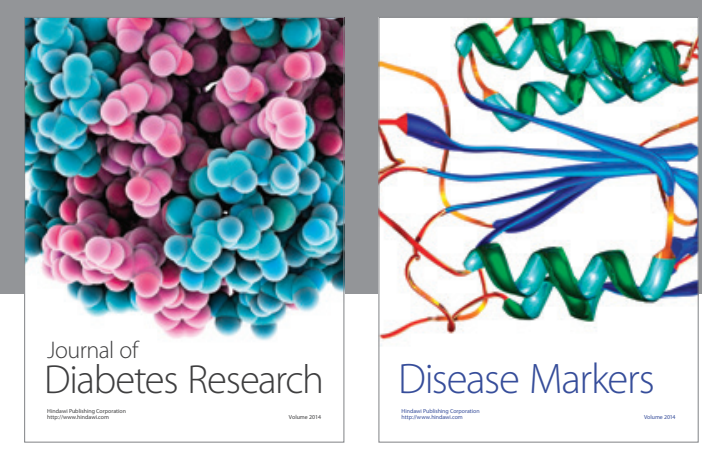

Disease Markers
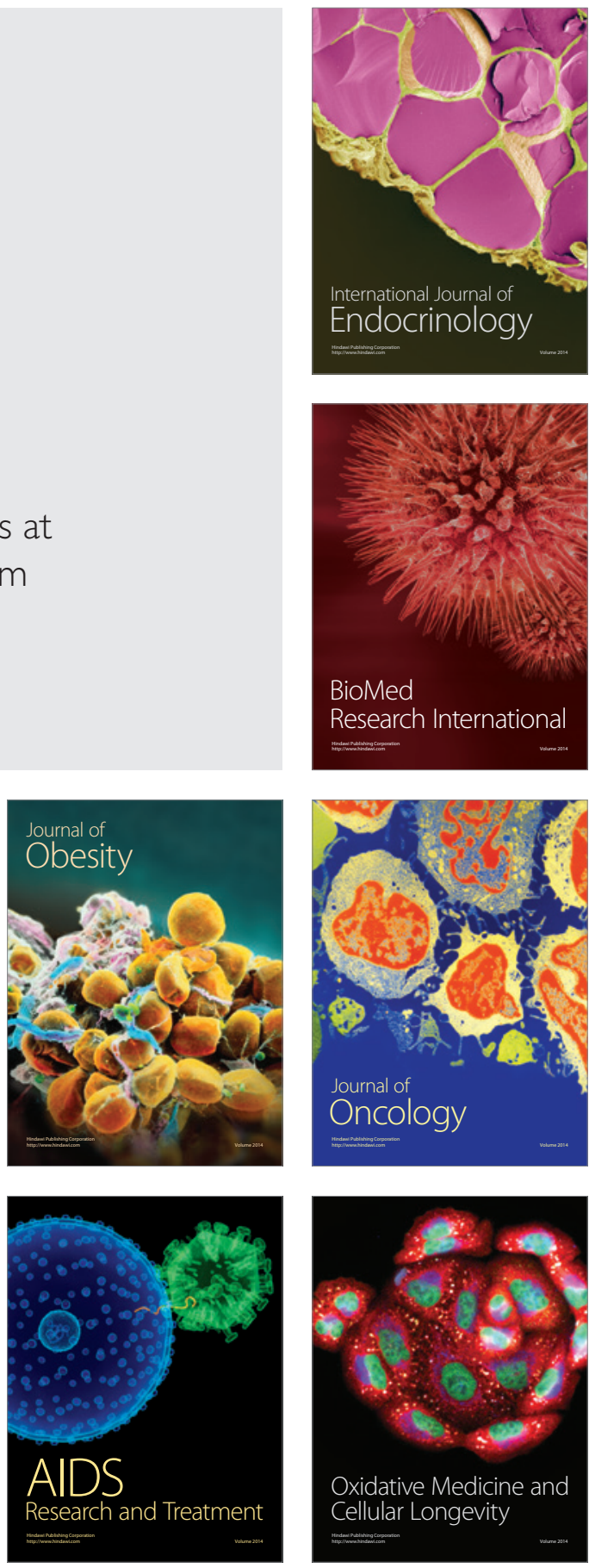